\section{Mathematical Model of Fatigue for Steel Wire Ropes}

\author{
Dušan Knežo \\ Department of Applied Mathematics and Informatics, Faculty of Mechanical Engineering, Letná 9, 04200 Košice, Slovak Republic
}

\section{BIOGRAPHICAL NOTES}

prof. RNDr. Dušan Knežo, CSc. is head of the Department of Applied Mathematics and Informatics. He graduated at the Faculty of Natural Sciences, University of P.J. Šafarik in Košice. He received the PhD.-degree at the Mathematic-Physics Faculty, University of J.A. Comenius in Bratislava, and he was habilitated at the Faculty of Mechanical Engineering, University of Žilina, in the scientific branch of applied mathematics. His scientific focus is oriented to the modelling of processes in the biomedical engineering, to the research of materials, as well as to the measurement and diagnostic equipment, prognostics and evaluation of medical proceed. He is a co-author of one monograph, one academic textbook and author of several textbooks. He has published more than 60 papers in the scientific journals and in the proceedings of the conferences and he has more than 80 quotations concerning his professional works. He was also incorporated in various grant research projects and industrial projects.

\section{KEY WORDS}

Steel Wire Rope, Rope Fatigue, Mathematical Model

\section{ABSTRACT}

The steel wire rope is stressed during operation by the tensile and bending forces. This loading state has a relevant impact on mechanical characteristics of the rope. A negative influence on the rope properties has a corrosion of the rope wires, especially. The wires are the basic construction components of the rope. It is necessary to know changes of rope mechanical characteristics with regard to a safety and reliability of the rope operation. In a case that the rope properties are not able to fulfil requirements of the safety and reliability, it is unavoidable to put-off such rope. There is presented in this paper a mathematical model describing dependence between prolongation of the rope and the number of loading cycles at various conditions. Such model enables to predict properties of the tested steel wire rope, as well as to estimate the put-off time of the rope.

\section{Introduction}

The steel wire rope is stressed and subjected to the corrosion during the current operation. There are changing mechanical properties of the rope due to the abovementioned factors. This fact has a negative influence on the operational safety and reliability. Therefore it is important to identify process of changing of the rope characteristics and, above all, to define correctly the time point of a dangerous or unreliable operation, i.e. to determine the rope put-off time. There was developed a mathematical model of the rope prolongation in relation to the number of working cycles using the experimental results obtained from three samples of the rope. This model enables to estimate mechanical properties of the tested rope, as well as the rope putoff time, eventually. 


\section{Parameters of the Tested Ropes}

The three rope samples, manufactured in Drôtovña, a.s. Hlohovec [8], were tested on the fatigue-testing machine. Each of the samples is wound unidirectionally with the next parameters [7]:

Table 1: Rope parameters.

\begin{tabular}{|c|c|}
\hline \multicolumn{2}{|c|}{ STN 024340.41 } \\
$\begin{array}{c}\text { Rope cross-sectional } \\
\text { construction }\end{array}$ & $6(1+9+9)+\mathrm{v}$ \\
\hline $\begin{array}{c}\text { Nominal tensile strength } \\
\text { of wires }\end{array}$ & $1570 \mathrm{MPa}$ \\
\hline $\begin{array}{c}\text { Nominal rope loading } \\
\text { capacity }\end{array}$ & $156,5 \mathrm{kN}$ \\
\hline
\end{tabular}

Table 2: Wire diameters.

Nominal wire diameters

\begin{tabular}{|c|c|}
\hline Core of strand & $1,6 \mathrm{~mm}$ \\
\hline The 1 st layer & $0,71 \mathrm{~mm}$ \\
\hline The 2 nd layer & $1,25 \mathrm{~mm}$ \\
\hline
\end{tabular}

The individual rope samples were tested at various conditions. The first sample was a new rope without primarily and consequently lubrication, with the length necessary for test on the fatiguetesting machine. Another two samples were situated into a corrosive ambient created by the $5 \%$ solution of the $\mathrm{NaCl}$ during 6 months [3]. After the Table 3: New rope without primary and subsequent lubrication. first three months one sample was lubricated subsequently. After 6 months both rope samples were tested at the fatigue-testing machine. The fatigue test was performed with one rope lubricated primarily, however without subsequently lubrication and with the second rope, which was lubricated primarily, as well as subsequently during operation. The producer of ropes applied the lubricant Elaskon and the same kind of lubricant was used for subsequently lubrication [7]. During the testing process was measured the prolongation $d$ of the rope depending on the number of loading cycles $n$. Note: in this paper there are given the values $n$ in thousands of loading cycles and the values $d$ are in millimetres.

\section{Mathematical model}

There was chosen a regressive function for each of the samples for simulation of the relation between the rope prolongation $d$ and the number of loading cycles $n$ according to the preliminary evaluation of the measured values. The regressive function is a polynomial

$$
d(n)=a_{0}+a_{1} n+a_{2} n^{2}+\ldots+a_{k} n^{k},
$$

$k \geq 1$, whereas it was defined for each of the samples the regressive function (1) for $k=1 ; 2 ; 3 ; 4 ; 5 ; 6$. The coefficients of the corresponding regressive function was found by means of the least square

\begin{tabular}{|c|c|c|c|c|c|c|c|c|}
\hline k & $a_{0}$ & $a_{1}$ & $a_{2}$ & $a_{3}$ & $a_{4}$ & $a_{5}$ & $a_{6}$ & $\sum\left(d_{i}-d\left(n_{i}\right)\right)^{2}$ \\
\hline 1 & 202,98 & 0,852 & & & & & & 349,4 \\
\hline 2 & 199,66 & 1,909 & $-0,0533$ & & & & & 288,9 \\
\hline 3 & 193,58 & 6,158 & $-0,6066$ & 0,0187 & & & & 95,0 \\
\hline 4 & 190,46 & 10,268 & $-1,6070$ & 0,0995 & $-0,0021$ & & & 36,4 \\
\hline 5 & 189,04 & 13,599 & $-2,9218$ & 0,2853 & $-0,0129$ & 0,00022 & & 19,9 \\
\hline 6 & 188,55 & 15,567 & $-4,0780$ & 0,5354 & $-0,0375$ & 0,00134 & $-0,000019$ & 16,9 \\
\hline
\end{tabular}

Table 4: Rope lubricated primarily without subsequent lubrication after 6 months in corrosive ambient.

\begin{tabular}{|c|c|c|c|c|c|c|c|c|}
\hline $\mathbf{k}$ & $\mathbf{a} \mathbf{a}_{\mathbf{0}}$ & \multicolumn{1}{|c|}{$\mathbf{a}_{\mathbf{1}}$} & \multicolumn{2}{c|}{$\mathbf{a}_{\mathbf{2}}$} & $\mathbf{a}_{\mathbf{4}}$ & $\mathbf{a}_{\mathbf{5}}$ & $\mathbf{a}_{\mathbf{6}}$ & $\sum\left(d_{i}-d\left(n_{i}\right)^{2}\right.$ \\
\hline 1 & 86,13 & 1,849 & & & & & & $\mathbf{1 0 6 1 , 2}$ \\
\hline 2 & 81,25 & 3,313 & $-0,0697$ & & & & & $\mathbf{9 2 3 , 4}$ \\
\hline 3 & 68,76 & 11,408 & $-1,0562$ & 0,0313 & & & & $\mathbf{7 4 , 9}$ \\
\hline 4 & 68,96 & 11,171 & $-1,0025$ & 0,0273 & 0,0001 & & & $\mathbf{7 4 , 6}$ \\
\hline 5 & 66,84 & 15,608 & $-2,6183$ & 0,2390 & $-0,0114$ & 0,00022 & & $\mathbf{3 9 , 1}$ \\
\hline 6 & 67,23 & 14,209 & $-1,8625$ & 0,0879 & 0,0024 & $-0,00036$ & 0,000009 & $\mathbf{3 7 , 3}$ \\
\hline
\end{tabular}


method. In the tables 1, 2 and 3 are presented the obtained results, including summations of the residual squares, where $d i$ is the value of prolongation measured for the number of loading cycles $n_{i}$.

From the tables 1,2 and 3 it is evident that in the case of all samples are summations of the residual squares for $k=1,2,3$, and 4 very large numerical values and they are significantly higher predominately than for $k=5$ and 6 , so the regressive models are not suitable for $k=1,2,3$, and 4 . Summations of the residual squares for $k=5$ and 6 are low numerical values sufficiently and they are different only few each other. Therefore it is possible, for simulation of the relation between the rope prolongation $d$ and the number of loading cycles $n$, to chose a regressive function for each of the samples for $k=6$, i.e.

$d(n)=a_{0}+a_{1} n+a_{2} n^{2}+a_{3} n^{3}+\ldots+a_{6} n^{6}$.

The satisfactory accuracy is verified also by means of the graphs of the measured values and dependences (2) presented on the Figs. 1, 2 and 3.

Table 5: Rope lubricated primarily and subsequently after 6 months in corrosive ambient.

\begin{tabular}{|c|c|c|c|c|c|c|c|c|}
\hline k & $a_{0}$ & $a_{1}$ & $a_{2}$ & $a_{3}$ & $a_{4}$ & $a_{5}$ & $a_{6}$ & $\sum\left(d_{i}-d\left(n_{i}\right)\right)^{2}$ \\
\hline 1 & 52,99 & 1,217 & & & & & & 1570,9 \\
\hline 2 & 50,38 & 1,904 & $-0,0287$ & & & & & 1529,4 \\
\hline 3 & 35,27 & 10,623 & $-0,9833$ & 0,0272 & & & & 254,9 \\
\hline 4 & 34,11 & 11,861 & $-1,2363$ & 0,0445 & $-0,0004$ & & & 246,6 \\
\hline 5 & 29,23 & 20,807 & $-4,1744$ & 0,3935 & $-0,0175$ & 0,00030 & & 62,3 \\
\hline 6 & 29,75 & 19,224 & $-3,4060$ & 0,2546 & $-0,0061$ & $-0,00014$ & 0,000006 & 59,4 \\
\hline
\end{tabular}

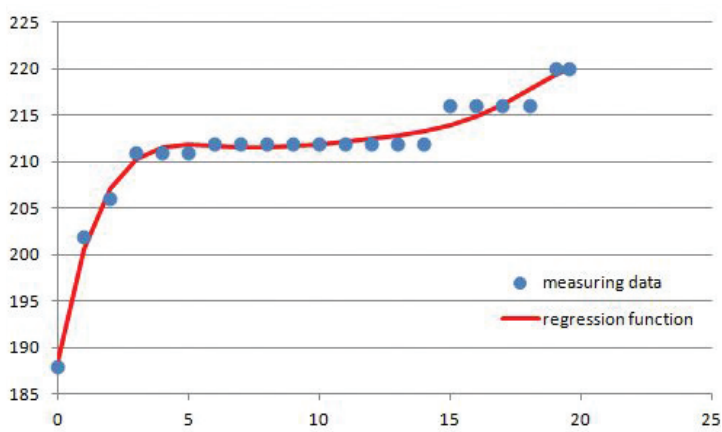

Fig. 1: New rope without primary and subsequent lubrication.

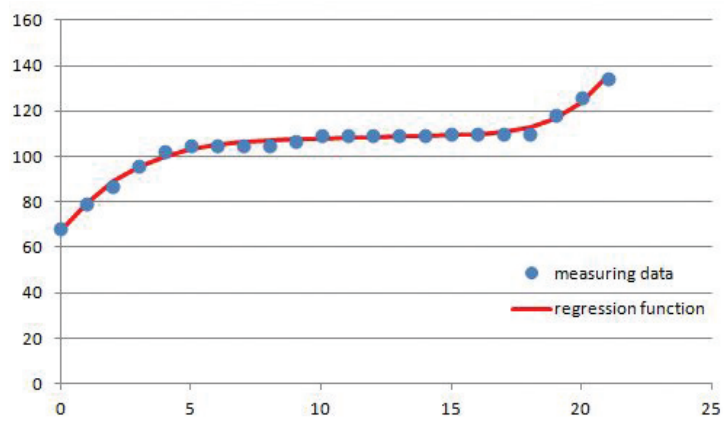

Fig. 2: Rope lubricated primarily without subsequent lubrication after 6 months in corrosive ambient.

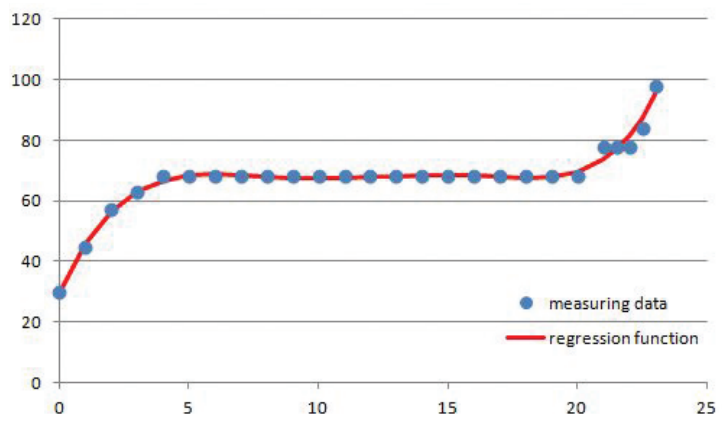

Fig. 3: Rope lubricated primarily and subsequently after 6 months in corrosive ambient.

\section{Conclusion}

It is possible to claim that the created regressive model is suitable and it enables to describe the dependence between the rope prolongation and the number of loading cycles with a sufficient accuracy. It can be also stated that for each of the samples exists an interval $\left\langle c_{L} ; c_{U}\right\rangle$, with a constant character of the function $d(n)$ or with a linear character with only a very small linear coefficient. This is validated also by means of a fact that for each of the samples exists an interval with the values of the first derivation $d^{\prime}(n)$ and the second derivation $d^{\prime \prime}(n)$ of function $d(n)$, which are very closed to the zero value (see illustrative Figs. 4 and 5). 


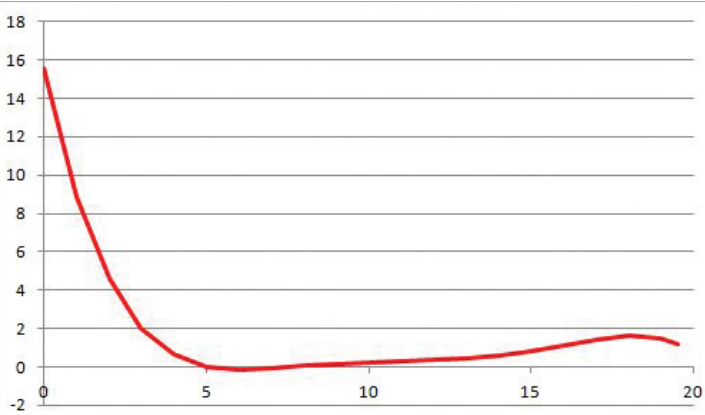

Fig. 4: The first derivation of function $d(n)$ for new rope without primary and subsequent lubrication.

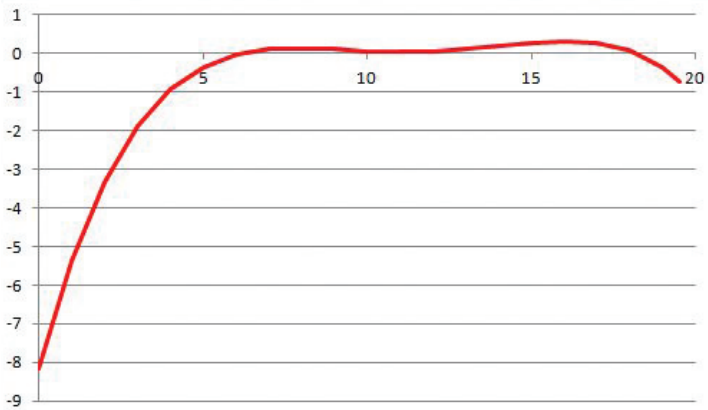

Fig. 5: The second derivation of function $d(n)$ for new rope without primary and subsequent lubrication.

There is defined in the work [5] the time point for the rope put-off like a moment of rope prolongation over $10 \%$ in comparison to the "stable" value. Determination of the rope put-off time can be defined alternatively like a such time point, which the function d(n) begins to lose its constant or linear character in. It can be applied also a fact that in a certain moment the values of the first derivation $d^{\prime}(n)$ and the second derivation $d^{\prime \prime}(n)$ of the function $d(n)$ are close to the zero value. How it was mentioned already, the established regressive model is a proper model and it makes possible to describe the mutual relation between the rope prolongation and the number of loading cycles with a conforming accuracy. So, it can be applied for an estimation of the loaded rope parameters, including prediction of the time-point for the rope put-off. However, it should be performed the more detailed statistical analysis based on a larger number of measurements of the same rope samples in order to verify the proximity level of a conformity between the model and the practice.

\section{References}

[1] Boroška, J., Hulín, J.,Lesňák, O., Ocel’ové laná, Alfa bratislava, 1982.

[2] Czaplicki, J. M., Nowe, górne oszacowanie rozkladu czasu trwalosci lin nosnych, In: IX. Medinárodná vedecko-technická konferencia TEMAG'2001.

[3] Floreková, L., Boroška, J., Bednárová, D., Marasová, D., Analýza výsledkov skúšok mechanických vlastností drôtov, In: Výskum, výroba a použitie ocel'ových lán, Katedra logistiky a výrobných systémov, Košice - Podbanské 1994.

[4] Hankus, J., Budowa i wlasnosci mechaniczne lin stolowych, GIG Katowice, 1990.

[5] Molnár, V., Knežo, D., Simulácie únavových skúšok ocel'ových lán, Proceedings of the 12-th International Conference Investigation, Production and Use Steel Wire Ropes, Podbanské, 2002

[6] Podlubný, I., Boroška, J., A model for simulation and prediction of reliability of steel wires. In: Výskum, výroba a použitie ocel'ových lán. Katedra logistiky a výrobných systémov, Košice - Podbanské 2000.

[7] Katalóg Ocelové laná. Drôtovňa, a.s. Hlohovec, 1999.

[8] Katalóg DEA Elaskon. GmbH Drážd’any, 1998.

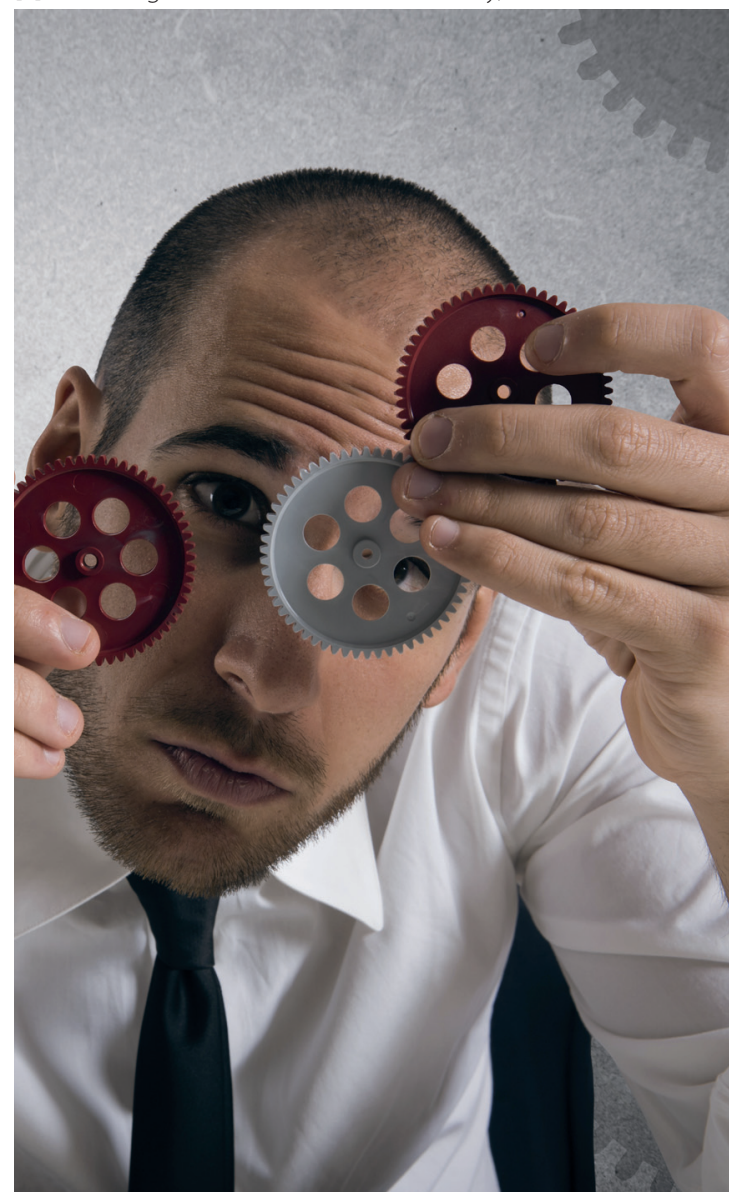

